\title{
The Overview of Security Theories and Concepts and the Example of the Republic of Bulgaria in Understanding the Problem of Security
} Přehled bezpečnostních teorií a konceptů a příklad
Bulharské republiky $v$ chápání problematiky bezpečnosti

\author{
Elitsa Petrova, Stoyko Stoykov
}

Abstract: Security and defence issues have always been the subject of scientific and artistic interest. The topicality of the researched issues is especially emphasized in the conditions of changing the concepts of security and bringing them from the traditional level to a level reflecting the modern reality. The article attempts to review the genesis and development of the security concept by presenting related and fundamental concepts, related and synonymous terms of the term "security", and various levels of security. The authors try to briefly describe the problem, which is reflected in a number of Bulgarian and international scientific and legislative sources, and which reflects the research purpose of the presented work.

Abstrakt: Otázky bezpečnosti a obrany byly vždy předmětem zájmu vědy a umění. Aktuálnost zkoumaných otázek je zdůrazňována zejména v podmínkách měnícího se chápání bezpečnosti a jeho přenesení z tradiční úrovně na úroveň reflektující moderní realitu. Článek se snaží zhodnotit vznik a vývoj konceptu bezpečnosti prezentací souvisejících a základních koncepcí, souvisejících a synonymických pojmů k pojmu „bezpečnost“ a různých úrovní bezpečnosti. Autoři se snaží stručně popsat problematiku, o které pojednává řada bulharských i mezinárodních vědeckých a legislativních pramenů a která reflektuje výzkumný účel prezentované práce.

Key words: Security; Defence; National Security; Public and Internal Security; Bulgarian Experience.

Klíčová slova: bezpečnost; obrana; národní bezpečnost; veřejná a vnitřní bezpečnost; zkušenosti Bulharska. 


\section{INTRODUCTION}

Security and defence issues have always been the subject of scientific and artistic interest and have provoked much discussion. Security has traditionally been seen as a complex system of high order representing a state that provides guaranteed protection of the vital interests of the individual, society and the state from any (external, internal, etc.) threats and even in a broad sense, security included only ways and means designed to protect people and their property from a variety of threats, including crime, natural disasters, industrial accidents, espionage, sabotage, coups or assaults.

This study focuses on changing security concepts and bringing them from the traditional level to a level reflecting modern reality, which we have tried to achieve by briefly describing the problem, where security concepts and theories and terms are research subject and the Bulgarian scientific and legislative experience and practice on security issues appears as a specific research object.

The method of content analysis was used through systematic search, discovery and analysis of scientific texts, primary and secondary data on the problem of examining the variety of concepts and theories of security from ancient times to the present day in order to assess and discover links and dependencies between different theoretical statements. The descriptive method was used to describe the characteristics of some related to the security terms. The research methodology included theoretical study of security concepts using theoretical study of the meaning, origin and etymology of the concept of security, similar, and related concepts, and consideration of the Bulgarian experience in terms of formulating the concepts of security and national security. Presenting information sources, including Bulgarian authors, foreign authors, legislative documents, consultations through the Cambridge Dictionary, the Collins Dictionary, the Merriam Webster Dictionary, the Online Etymology Dictionary contributed to a greater understanding of the origins and development of security concepts.

\section{GENESIS AND DEVELOPMENT OF THE CONCEPT OF SECURITY - BRIEF OVERVIEW}

Since ancient times, the term "security" has been understood as the inability to cause harm and as the protection of each person and his environment from extreme danger. The term appeared in the middle of the 15th century with the meaning of "condition for the creation of security" and derived from the Latin words "securitas, securus" "without care". The meaning of "something that provides" dated back to the 1580s, and the meaning of "security of state, man, etc." dated back to $1941 .{ }^{1}$ In the 1970 s, began to be considered that long-lasting security could not be achieved alone, but only in

1 Online Etymology Dictionary 2001-2021. Security. Douglas Harper. https://www.etymonline.com/word/ security, available on 05.12.2020. 
cooperation in an interdependent world. Today, all countries recognize that we live in an infinitely dynamic world and that it is very difficult to be both adversaries and partners.

According to the Merriam Webster Dictionary, the meaning of the word is "quality or condition such as freedom from danger, safety; freedom from fear or anxiety; freedom from the prospect of job cuts; something that provides protection; measures taken to prevent espionage or sabotage, crime, assault or escape". ${ }^{2}$ According to the Cambridge Dictionary the term "security" means "protection of a person, building, organization or state from threats such as crime or attacks by foreign states; the fact that something is unlikely to fail or be lost; the feeling of confidence in the family and society; the protection of people, organizations, countries, etc. against a possible assault or other crime". ${ }^{3}$

Traditionally, the term "security" means a state of lack of threat, of being safe or free from danger, fear and anxiety, a state of peace, without any risks and threats. The term encompasses a wide range of meanings, from "feeling safe" to "a state without risks and worries" and includes ways and means designed to protect people and their property from a variety of threats, including crime, natural disasters, industrial accidents, espionage, sabotage or assaults.

Discussions about security often involve the mention of related terms that become interchangeable, equated with each other or used as synonyms. Some of the synonyms of the word are accuracy, infallibility, confidence, conviction, faith, steadfastness, guarantee, insurance, safety, integrity, preservation, calmness, firmness.

The related term "safety" appeared in the early 14th century, from the Old French word "sauvete" with meaning "protection, salvation, security" and from the medieval Latin word "salvus" - "unharmed, in good health, safe". The meaning of "accident prevention" appeared in $1873 .{ }^{4}$ According to the Cambridge Dictionary, "safety" means "no danger; a state in which no one or nothing threatens us, security, protection, asylum, condition to prevent suffering or causing injury or loss; state of protection from danger or harm; equipment, rules, etc. that are designed to protect people from injury". ${ }^{5}$ The opposite of it term "danger" derived from the Anglo-French word for "power, authority, control, opportunity to harm". Since the beginning of the 13th century, the word has meant the harmful influence including "beating, arrogance, impudence". The modern meaning "risk, danger, exposure to injury, loss, pain" and "controlling someone or something" dated back to the late 14 th century. ${ }^{6}$ Nowadays, danger is the possibility of causing harm, death, injury someone, or something unpleasant.

2 Merriam Webster Dictionary 2001-2021. Security. Merriam-Webster, Incorporated. https://www.merriamwebster.com/dictionary/security\#synonyms, available on 05.12.2020.

3 Cambridge Dictionary 2021. Security. Cambridge University Press. https://dictionary.cambridge.org/ dictionary/english/security, available on 05.12.2020.

4 Online Etymology Dictionary 2001-2021. Safety. Douglas Harper. https://www.etymonline.com/word/ safety, available on 05.05.2021.

5 Cambridge Dictionary 2021. Safety. Cambridge University Press. https://dictionary.cambridge.org/ dictionary/english/safety, available on 05.05.2021.

6 Online Etymology Dictionary 2001-2021. Danger. Douglas Harper. https://www.etymonline.com/word/ danger, available on 05.05.2021. 
In the search for new conceptions of security, the idea of the threat gradually took basic place building an effective image of the analysis of the security environment. Based on this image, actions are organized and taken to generate and maintain the balance of competing participants in the space they share. Originating in the Old English the meaning of term "threat" is "detachment, oppression, coercion", which is related to the word "preotan" - "trouble, tired", originating in the Proto-Germanic with meaning of "pressure, oppression". In the Old Church Slavonic language, the term referred to "oppression", and in Old Welsh language it referred to "suffering". The modern meaning of "conditional declaration of hostile intent" is derived from English.7 According to the Collins Dictionary, "threat" means intention or determination to punish, injure, etc., as revenge for some action; an indication or warning of possible problems or the risk of something terrible; a person or something that threatens, danger of something unpleasant happening; a statement by someone that they will do something unpleasant. ${ }^{8}$

The analysis of the concept of "security" would not be complete if we do not mention its differences with two other important concepts - the concepts for "peace" and "defence" with which security was until recently considered close and almost identical. In the UN Charter, the combination "peace and security" is used 105 times and in practice, in the UN Charter "peace" and "security" are synonymous.

Other concepts of security seek the significance of it in economic terms and define it as an individual and public good, accessible equally to every member of society. According to Abraham Maslow's hierarchy of needs, the need for "safety" and "security" is in second place in the levels of motivating factors. This need is directly situated above the basic physiological human needs as hunger, thirst, sleep, etc. which are at a basic level of the hierarchy of human needs. The security depends mainly on building the conditions in which fair relations can develop in society, partly by reducing antagonism between actors, with the presumption that their basic needs can be met and that synchronicity in the differences of their interests can be agreed and achieved. ${ }^{9}$ In this case, the means of achieving security include the use of security systems; warning systems; diplomatic means and social impact; coercive possibilities; policy for the development of sustainable economic, physical, environmental and other security elements.

For a long time, the security of a system has been considered a static state in which the normal existence of the individual or society is guaranteed and their vital interests are reliably protected, and if a threat to these interests arises, the system will not be secure and will enter state of uncertainty. Therefore, security was considered as the functional state of a system, which provided neutralization and counteraction to external and internal factors that affect or may have a destructive effect on the system, i.e.

7 Online Etymology Dictionary 2001-2021. Threat. Douglas Harper. https://www.etymonline.com/word/ threat, available on 05.05.2021.

8 Collins Dictionary 2021. Threat. Collins. https://www.collinsdictionary.com/dictionary/english/threat, available on 05.05.2021.

9 Gee, D 2016. Rethinking Security: A discussion paper. Rethinkingsecurity.org.uk. Ammerdown Group. https://rethinkingsecurityorguk.files.wordpress.com/2016/10/rethinking-security-a-discussion-paper. pdf, available on 05.05.2021. 
a static state of society without the danger of political and economic coercion, in which the basic interests and freedoms of citizens are guaranteed.

In a historic debate on how to achieve security, Hobbes, Machiavelli, and Rousseau tend to paint pessimistic pictures in which the international system is seen as a stage in which states will seek to achieve their own security at the expense of their neighbours and in interstate relations there will be a struggle for power, in which each state will constantly try to take precedence over another. According to realism in international relations, lasting peace is unlikely to be achieved. ${ }^{10}$ The liberal school of international relations and security dates back to the ideas of Immanuel Kant. Liberalism presupposes that economic openness and interdependence between countries makes them more peaceful than countries that are isolated and view international institutions as a key factor in avoiding conflicts between peoples and contributing to world peace. ${ }^{11}$ In the 1980 s, constructivism became the most influential approach in international security research $^{\mathbf{1 2}}$, according to which security was a social construct, emphasizing the importance of social, cultural, and historical factors. In 1998, Barry Buzan examined international security from the perspective of threats that could be tolerated and those that required immediate action. ${ }^{13}$

Traditional security research has limited the subject to politico-military issues, while Buzan, Waever, and de Wilde expanded the concept of security by focusing on the economic, social, and environmental sectors of society. Buzan, Waever, and de Wilde, who presented security not as a state but as a process did a complex attempt to synthesize the concept of security and to engage security analysis with contemporary social theory. ${ }^{14}$

In 2001, a report by the International Commission on Intervention and State Sovereignty emphasized that the protection of the individual is more important than the protection of the state and a collective understanding of the deepest social issues is needed to prevent humanitarian crises. ${ }^{15}$ During the years the European Union adopts a second-generation human security approach to conflicts, as an alternative to Geo-Politics

10 Baylis, John (2011). The Globalization of World Politics (fifth ed.). New York: Oxford University Press Inc. p. 234. ISBN 978-0-19-956909-0.

11 Navari, C. (2008). Liberalism. Security Studies: An Introduction. P. D. William. New York, Routledge.; Rousseau, D. L. (2010). Liberalism. The Routledge Handbook of Security Studies. M. D. Cavelty and V. Mauer. New York, Routledge.

12 McDonald, M. (2008). Constructivism. Security Studies: an Introduction. P. D. William. New York, Routledge.

13 Buzan, B. 2000. Change and Insecurity reconsidered. Critical Reflection on Security and Change. S. Croft and T. Terriff. Oxen, Frank Cass Publishers.

14 Buzan, B., Ole Waever, Jaap de Wilde 1998. Security - A New Framework for Analysis. Lynne Riennner Publishers. London.

15International Commission on Intervention and State Sovereignty (2001). The Responsibility To Protect. International Commission on Intervention and State Sovereignty. Publisher(s): IDRC. https://www.idrc. $\mathrm{ca} / \mathrm{en} / \mathrm{book} /$ responsibility-protect-report-international-commission-intervention-and-state-sovereignty, достьпно на 03.02.2021. 
or the War on Terror. Second generation human security takes forward the principles of human security and adapts them to 21 st century realities. ${ }^{16}$

The new Security Paradigm expands the state security perception by focusing on the individual and community security rather than the state security. ${ }^{17}$ As noted in General Assembly resolution 66/290, for many people, today's world is an insecure place, full of threats on many fronts. Protracted crises, violent conflicts, natural disasters, persistent poverty, epidemics and economic downturns impose hardships and undercut prospects for peace, stability, and sustainable development. Such crises are complex, entailing multiple forms of human insecurity. Human security is a people-centred, comprehensive, context-specific and prevention-oriented responses that strengthen the protection and empowerment of all people. ${ }^{18}$

The placement of the individual as the main object of protection is the basis of the humanistic understanding of national security, which makes it possible to identify and assess the threats to him as accurately as possible. On this basis, what we call a new understanding of national security is formed, allowing the parallel solution of the following tasks: preventing military opposition and conducting military operations; prevention of conditions and prerequisites for major industrial accidents; termination and limitation in practice of the harmful ecological impact of the production; a developed civil society, which is divided by the three authorities, which in turn guarantee transparency and control of governance; preventing economically unprofitable production from functioning; preserving and increasing the cultural and historical heritage of the nation; preventing the loss of social benefits in the field of education and health; prevention of loss of territory.

\section{WAR, DEFENSE, SECURITY AND DEFENSE OF THE INDIVIDUAL, NATION AND WORLD}

For many years in human history, rival armies of different nations had settled political disputes on the battlefield. The first armed conflict in the history of the world, recorded by eyewitnesses, was the battle of Megiddo in 1479 BC (Armageddon, well known from the biblical Book of Revelation as the site of the final battle between good and evil)

16 The Berlin Report of the Human Security Study Group, 2016. From Hybrid Peace to Human Security: Rethinking EU Strategy towards Conflict, Presented to the European External Action Service, 24 February 2016. Brussels. http: //www.securityintransition.org/publications/berlin-report-of-the-human-securitystudy-group/, available 21.10.2021.

17 Novotny, T. 2016. Human Security Pardigm. $7^{\text {th }}$ Medzinárodná vedecká konferencia Národná a Medzinárodná Bezpečnost' 2016. Akadémia ozbrojených síl generála M. R. Štefánika, Liptovskom Mikuláši, Katedra bezpečnosti a obrany. http://www.aos.sk/struktura/katedry/kbo/NMB2016/Zbornik_NMB_2016. pdf, available 21.10.2021.

18 General Assembly 2012. Resolution adopted by the General Assembly on 10 September 2012. United Nations Official Document https://www.un.org/en/ga/search/view_doc.asp?symbol=A/RES/66/290, available 21.10.2021. 
between Egypt and a union of former Egyptian territories. ${ }^{19}$ This model for resolving territorial disputes was also used by many nations, whether citing the success of Scipio Africanus $(236-183 \mathrm{BC})$, the defeat of Carthage and the rise of Rome or the military victories of Philip II Macedonian (382 - 336 BC). As a state of open armed conflict between political entities such as sovereign states or between rival political or social factions within a country the war can be defined as armed hostilities between two or more states or groups; any situation in which there is strong competition between opposing parties or a struggle against something; a situation in which different systems compete very strongly with each other. ${ }^{20}$ The word comes from the late Old English word "wyrre" -"large-scale military conflict", from the Old French language "were" - "war, difficulty, dispute, battle", Old German "werran" - "to confuse", while the Romans borrowed the word "war" from the German language to avoid using the Latin word "bellum", which merged with "bello" - "beautiful". One modern reference dated back to 1775 as a "warpath", with a reference to the North American Indians. ${ }^{\mathbf{2 1}}$

Referring to military activities, Aristotle linked security and defence concepts by associating the concept of security ("ataraxia") with the expression of courage in the face of the enemy and in particular the moment before an attack. However, he also transferred the definition to the manifestation of a higher feeling in the face of every terrible and terrible circumstance, which is the harmony of the soul. Security, described as "ataraxia", had its connotative meaning associated with the battlefield and denoted a person who could control the emotions of fear and anxiety. Epicurus concluded that "ataraxia" was a softer term for security than the word "asphaleia" which was firmer and stronger form of the term. In ancient Greek literature term "asphaleia" was often used to describe combat success, giving stony character and physical strength to the hero. Xenophon used the terms to describe the security of a military attack, regarding the safe passage of a military threat, protection from civil or political attacks. Demosthenes identified military and financial power as the basis of security. ${ }^{\mathbf{2 2}}$

Due to the fact that practically the security is primarily concerned with the management of physical threats and military capabilities, it is often understood as the capacity of a nation to mobilize military resources to secure its borders and deter or successfully protect them against physical threats, foreign military aggression and attacks by terrorist groups. In military science the term "defence" refers to all military resources and the art of defending a nation, alliance and territory from external attack, preventing damage to human or resources, or conquering territory from the enemy, and often is associated both with the ability of a country's government to form and maintain an army, naval

19 Mark, J. 2009. War in Ancient Times. Ancient History Encyclopedia. https://www.ancient.eu/war/, available on 05.05.2021.

20 Cambridge Dictionary 2021. War. Cambridge University Press. https://dictionary.cambridge.org/ dictionary/english/war, available on 05.05.2021.

21 Online Etymology Dictionary 2001-2021. War. Douglas Harper. https://www.etymonline.com/word/war, available on 05.05.2021.

22 Baev, G. 2017. Metaphysics of security. Exploring the ethical links between security and happiness in the focus of philosophical issues. International Science Conference "CONFSEC", Year 1, Issue 1, Publisher Scientific Technical Union of Mechanical Engineering. 
forces and military aviation to defend the country, and with the ability to use these forces in the event of an attack by other countries.

Defence covers all actions against attack; a set of means of protection from the enemy; actions to ensure the country's defence; system of means and actions for protection of the population in case of disasters; methods used to avoid another person, organization or country to take control. ${ }^{23}$ The word dated back to the early 1300 s, with meaning of "action to guard, prevent attack or injury", "act of defence by combat", "fortified place of refuge" and derived from the Old French word "defence" and from the Latin word "defensus" with meaning "repel, protect, something protected". The meaning of "speech or writing intended to repel or refute an accusation" dated back to the end of the 14th century. The meaning of "science of defence against attack" dated back to the mid-1600s. The term was used until 1935 as a euphemism for "national military resources" and "man of defence, warrior".24

After the end of World War II, the United States formally replaced the term "defence security" with the term "national security". ${ }^{25}$ For most Americans, the United States has long been in a state of security, but since 1945 this invulnerability has diminished and the concept of national security has been rethought. For the first time, American leaders are confronted with one of the paradoxes of the security: "If you want peace, be ready for war." 26

The term "national security" was first used by US President Theodore Roosevelt in his address to Congress in 1904, justifying the accession of the Panama Canal zone to national security interests, and the first definition of national security was given by Walter Lipman, according to whom the national security is a state when a country does not have to sacrifice its legitimate interests in order to avoid war and when it is able to defend its interests if necessary by waging war. ${ }^{27}$ National security is a state of security and protection of a nation, including its citizens, economy and institutions, usually seen as an obligation of the government. Initially, the term was used with meaning of protection against military attacks, and currently it includes non-military actions, crime minimization, economic, energy, social security, environmental security, security against terrorism, cybersecurity, etc.

In the most general form, the national security of a country, according to the UN Charter, means a dynamic state in which there is no direct danger to the state and

23 Cambridge Dictionary 2021. Defence. Cambridge University Press. https://dictionary.cambridge.org/ dictionary/english/defence, available on 05.05.2021.

24 Online Etymology Dictionary 2001-2021. Defense. Douglas Harper. https://www.etymonline.com/word/ defense, available on 05.05.2021.

25 Yonchev, D. 2020. University Vocabulary - Basic Concepts, Security. NBU. https://nbu-rechnik.nbu. $\mathrm{bg} / \mathrm{bg} /$ obsht-spisyk-na-ponqtiq/sigurnost, available on 05.05.2021.

26 Jablonsky, David 2012. Why is strategy difficult? In U.S. Army War College Guide to National Security Issues Volume I: Theory of war and strategy. 5th Edition J. Boone Bartholomees, Jr. Editor. Strategic Studies Institute Book.

27 Lippmann, W. 1944. U.S. Foreign Policy. London, Hamish Hamilton. 
society of armed attack, political pressure or economic coercion, so the countries can freely carry out their development and progress. ${ }^{28}$ National security is also associated with:

- a freedom from foreign influence (Harold Laswell, 1950); ${ }^{\mathbf{2 9}}$

- a nation's ability to preserve its physical integrity and territory, to maintain economic relations with the rest of the world at a reasonable cost, to preserve its essence, institutions and governance, and to control its state borders (Harold Brown, 1977); $;^{30}$

- one's own self-determination or autonomy, prosperity and well-being. (Charles Mayer, 1990); 31

- a state of a nation's ability to overcome multidimensional threats to its well-being and survival by balancing all instruments of public policy and is therefore an element of global security. (Prabhakaran Paleri, 2008) 32 $^{32}$

As a function of government, public security ensures the protection of citizens, organizations and institutions against threats to their well-being, thus favouring the prosperity of the community. Public security contributes significantly to the productivity and overall success of an economy and prevents and resists events such as pandemics, industrial accidents, environmental disasters and terrorist attacks, which pose additional threats to public security and order.

Security theory is largely based on the thesis that the state has a vital role to play in ensuring national security. In order to realize its functions, the state carries out continuous activities for the protection of national security in several relatively separate areas political, economic, social, environmental, information, military, demographic, energy and others. Internal or homeland security is a term that characterizes national efforts to ensure that a country is safe, secure and resilient to threats related to increasing vulnerability and from attacks that occur against it. Internal security is an act of preserving peace within the borders of a sovereign state by upholding national legislation. Its scope includes: ${ }^{33}$

- physical protection of an individual;

28 United Nations 1945. United Nations Charter. United Nations. https://www.un.org/en/about-us/uncharter, available on 05.05.2021.

29 Romm, J. 1993. Defining national security: the nonmilitary aspects. Pew Project on America's Task in a Changed World (Pew Project Series). Published by the Council on Foreign Relations Press, 58 East 68th St., New York, NY 10021. Annotation copyright by Book News, Inc., Portland.

30 Brown, Harold 1983. Thinking about national security: defense and foreign policy in a dangerous world. As quoted in Watson, Cynthia Ann (2008). U.S. national security: a reference handbook. Contemporary world issues (2 ed.). ABC-CLIO. https://archive.org/details/usnationalsecuri0000wats/page/280/mode/2up., available on 03.02.2021.

31 Maier, Charles 1990. Peace and security for the 1990s. Unpublished paper for the MacArthur Fellowship Program, Social Science Research Council, As quoted in Romm 1993.

32 Paleri, Prabhakaran 2008. National Security: Imperatives and Challenges. New Delhi: Tata McGraw-Hill.

33 McElreath, D., Jensen, Carl, Wigginton, Michael, Doss, Daniel, Nations, Robert; Van Slyke, Jeff 2014. Introduction to Homeland Security (2nd ed.). Boca Raton, Florida: CRC Press. 
- protection of the territory, sovereignty, population and critical infrastructure of the country against external threats and aggression;

- preparedness and response to threats of natural disasters;

- border control, including at land, sea and air borders;

- transport and security logistics;

- preparedness and response to threats of terrorism;

- protection through domestic and international intelligence activities;

- criminal investigation and counteraction against illegitimate subjects, in case of financial abuses, drug trafficking, smuggling, human trafficking;

- environmental and bio protection, detection of radioactive materials;

- IT security technologies and cyber protection;

- investigation of transnational criminal organizations.

The responsibility for the homeland security is assumed by the Ministry of Interior, and in certain cases by the Ministry of Defence. Depending on the specific legislation, it is maintained by the police, gendarmerie, militarized security forces, border authorities, special police units, state intelligence agencies, etc.

On 12 December 2003, at the Brussels Summit, the European Council adopted the European Security Strategy, according to which the period of violence of the first half of the 20th century gave way to an unprecedented era of peace and stability in the continent's history. The main threats formulated in the Strategy are in the relation with international or global security and ranked in order of importance as follows: the terrorism; the weapons of mass destruction; the regional conflicts with impact on European borders and the collapse of the state due to poor governance (corruption, abuse of power, poorly functioning institutions, lack of accountability) and civil conflicts. ${ }^{34}$

An interesting definition of international security was proposed by Nayef Al-Rodhan, according to whom the global security had five dimensions, which include human security, environmental security, the national dimension, the transnational and transcultural dimension of security, where global security cannot be achieved without good governance at all these levels. ${ }^{35}$ Therefore, the international or global security refers to measures taken by states or international organizations to ensure mutual survival, security and protection from traditional or conventional military action and conflict; application of economic force; ethnic, religious and ideological conflicts; threats to human security and the destabilization of states through environmental degradation, infectious diseases, climate change and illegal activities of non-state actors.

34 Ivanov, V. 2011. Bulgaria in the modern unions of Europe. Academy of the Ministry of Interior, Sofia.

35 Al-Rodhan, Nayef R.F. 2007. The Five Dimensions of Global Security: Proposal for a Multi-sum Security Principle. Berlin: LIT Verlag. ISBN 978-3-8258-0478-7. 


\section{THE SECURITY CONCEPTS IN BULGARIAN SCIENCE AND PRACTICE}

The history of modern civilization has proven the need for people to work together, to unite their efforts, which leads to cooperation in achieving common goals. The new century requires organizations with a new vision and mission in which to direct people's efforts. ${ }^{36}$ The modern security environment, being dynamic, unpredictable, hazardous and limited in resources is a challenge for the member-countries of Euro-Atlantic structures. Respectively, Bulgarian Armed Forces and internal security forces reforms prolonged for more than 20 years, which resulted in lack of personnel and unfulfilled modernization, therefore the question can be asked whether the defence capabilities of the country are good enough to ensure the safety of the Bulgarian territory as well as our national and the international security. ${ }^{37}$

The fact that the entire system of national security has been created and continues to exist in such a way that the state is a major factor in ensuring the security of society and the individual is a product of a certain stage of social development. ${ }^{38}$ The state builds the legal framework and guarantees the operation of constitutions and laws by enshrining a certain system of norms, the observance of which is encouraged, and the violation is sanctioned by the state authorities.

In their attempts to explain the concept of security the Bulgarian scholars and practitioners give it a variety of characteristics. According to Prodanov, security is a system's ability to be preserved in the event of a change in the environment, conditions and circumstances on which it depends, therefore, to function and develop optimally at the lowest cost of resources and objectives set in it. ${ }^{39}$ Stefanov defined security as safety and a state of guaranteed reliability. According to him, the security exists when the basic needs, values and interests of the system are not threatened by such impacts that the system cannot managed or neutralized. ${ }^{40}$ According to Yonchev, security is a state of calm and confidence that there is no threat or danger to the individual or the system. ${ }^{41}$ Peev considers that without satisfying the need for security, the masses cannot satisfy the needs of a higher rank, such as the needs for development and self-improvement. ${ }^{42}$

36 Atanasova - Krasteva, N. 2012. Leadership building of cadets, Publishing Complex of Vasil Levski National Military University, Veliko Tarnovo.

37 Dimitrova, Sevdalina, Nikolay Kamarashev, Criteria for Efficient Defence Product Life Cycle Management, International Conference Knowledge-based Organization Vol. XXIV No 1 2018, 279-282, DOI: 10.1515/ kbo-2018-0044.

38 Angelov, K. 2008. Information and communication technologies as a strategy for prevention and counteraction of corruption. Ed. Avangard prima, $\mathrm{S}$.

39 Prodanov, V. 1995. Internal security and the nation state. Military Journal No. 2. S., Bulgaria.

40 Stefanov, G. 2005. Theory of International Security. SIELA Publishing House.

41 Yonchev, D. 2020. University Vocabulary - Basic Concepts, Security. NBU. https://nbu-rechnik.nbu.bg/bg/ obsht-spisyk-na-ponqtiq/sigurnost, available on 05.05.2021.

42 Peev, Ilia 1996. Psychological Aspects of Security, pp. 33-46, in: Security through Partnership and Integration. Bulgaria, NATO and the European Security Architecture, BEXA, Sofia. 
Introducing the concept of modern security in Bulgarian science, Slatinsky comprehensively considered and summarized the diversity of its all theoretical and practical aspects and offered five levels of security connected with the security of the individual, called personal or individual security; security of the group of people - group security; state security, which is related to the protection of ancient values: territorial integrity, independence, sovereignty, constitutional order; security of community and security of the world, of the planet, i.e. global, universal, common security. ${ }^{43}$ According to Slatinsky, the levels of the individual's, group's, and state's security determine the national security, while the levels of the state security, security of the community, and the security of the world determine international security ${ }^{44}$, which is similar to the approach of Copenhagen School researchers Buzan, Waever and de Wilde, who considers five levels of analysis in international relations, which leads Bulgarian science closer to the perception of security not as a static state, but as a process in dynamics and constant change.

The concept of national security of the Republic of Bulgaria was first formulated by the concept of national security in the country in 1998, which was developed in the legislation through the Law on Protection of Classified Information and the Law on the State Agency for National Security. According to the concept, national security exists when the fundamental rights and freedoms of Bulgarian citizens, state borders, territorial integrity and independence of the country are protected, when there is no danger of armed attack, forcible change of the constitutional order, political dictate or economic coercion for the state and the democratic functioning of state and civil institutions is guaranteed, as a result of which the society and the nation preserve and increase their well-being and develop themselves. ${ }^{45}$

National security is aimed at increasing the feeling of security among the citizens by creating the necessary conditions and prerequisites for ensuring national interests, limiting the impact of risks and threats and the optimal allocation of resources. ${ }^{46}$ National security policy is a set of interrelated priorities and sectoral policies that have equal importance and equal impact on the national security system. Article 2 of the Basic Law in the field of security states that national security is a dynamic state of society and the state, in which the territorial integrity, sovereignty and the constitutionally established order of the country are protected, when the democratic functioning of institutions and the fundamental rights and freedoms of citizens, as a result of which the nation preserves and increases its welfare and development, as well as when the country successfully defends its national interests and realizes its national priorities. ${ }^{\mathbf{4 7}}$

43 Slatinsky, N. 2000. Security dimensions. Paradigma Publishing House, Sofia.

44 Slatinsky, N. 2010. The five levels of security. Military Publishing House, Sofia.

45National Assembly of the Republic of Bulgaria 1998. Concept for national security of the Republic of Bulgaria. Decision of the National Assembly of 16.04.1998.

46 National Assembly of the Republic of Bulgaria 2011. National Security Strategy of the Republic of Bulgaria. Decision of the National Assembly of 08.03.2011.

47 National Assembly of the Republic of Bulgaria 2015. Law on Management and Functioning of the System for Protection of National Security. National Assembly of the Republic of Bulgaria. In force from 01.11.2015, State Gazette issue 61 of 11 August 2015, amended State Gazetteissue 94 of 13 November 2018, amended State Gazette No. 69 of August 4, 2020. 
The National Security Policy of the Republic of Bulgaria with its integral components is aimed at maintaining the readiness of institutions, society and citizens to respond in conditions of high dynamics of the security environment ${ }^{48}$, as well as to create conditions for the realization of the interests of Republic of Bulgaria. It is obvious from the Concept for National Security of the Republic of Bulgaria that today the security is perceived not only as a state but as an action and changing and dynamic process.

\section{CONCLUSION}

Historically based on the concept of security as harmlessness, protection of the individual, group, organization, nation and world and accepting it as free from danger, fear and anxiety, a state of peace, without any risks and threats, considering related terms and concepts such as defence, protection, preservation, safety, and even using antagonistic terms as "war" and "peace", "threat" and "protect", today more than ever we notice and discover a very wide scope of security, with an emphasis on the human security.

Security undoubtedly emerges from its static state and enters its dynamic form of existence, acquiring the essence of movement, development and continuous progress. Nowaday, the scope of security includes threats in various areas such as economics, health, environment, social environment, demography, religion, forms of culture, way of life, tradition, customs, politics, individual protection and protection of property, protection of community, where the broader concept of security includes protection against epidemics and communicable diseases, the fight against terrorism and organized crime, safe transport and food security, energy protection, combating devastating climate change, peace and global development initiatives. and many others who laid the foundations of the concept of human security.

The strategic security environment is characterized by high dynamism and unpredictable growing, and changes in it depend on the growing influence of non-military (asymmetric) risks and threats, typical of the beginning of the 21st century. The expansion of bilateral and regional cooperation and partnership, as well as the joint work on projects in these areas contribute to the stabilization and full integration of the countries in the Euro-Atlantic and European space. The participation of the Republic of Bulgaria in the collective defence of NATO and in the Common Security and Defense Policy of the EU is both a reliable means of protecting its national interests and a form of defending the solutions to the global problems important for the society.

48 Krastev, K. 2016. Determinant analysis of external influence on the Bulgarian national security policy. International conference Knowledge-based organization Vol. 22, No. 1. 
Authors: Assoc. prof. Elitsa Petrova, PhD in Economics and Management and DSc. in Security and Defence, born 1978. A graduate of "St. St. Cyril and Methodius" University (2003). She worked at leadership and teaching positions in the management and social field. Currently active as lecturer, LEARepresentative for Horizon, Departmental Coordinator of Erasmust. She focuses on the topic of Management, Strategic Management, Human Resources Management, Project Management, Management of Innovation, Organizational Behaviour. She is the author of 3 own monographs, co-author in 4 monographs, 5 published textbooks, over 130 articles in domestic and foreign journals.

Prof. Dr. Stoyko Stoykov, DSc., born 1955. Graduated from the Higher Military School in Shumen (1978), Military Academy in Sofia (1985). He has held leadership and teaching positions in the field of security and defense. Currently active as a research scientist. It focuses on the topic of security and defense management. He is the author of 4 monographs and a number of expert articles in Bulgarian and foreign journals.

How to cite: PETROVA, Elitsa and Stoyko STOYKOV. The Overview of Security Theories and Concepts and the Example of the Republic of Bulgaria in Understanding the Problem of Security. Vojenské rozhledy. 2021, 30 (4), 109-122. ISSN 12103292 (print), 2336-2995 (online). Available at: www.vojenskerozhledy.cz 